\title{
CATEGORIES OF CONSTITUTIONAL NORMS ${ }^{1}$
}

This article deals with a field of constitutional law, the fundamental theory of written constitutions. The relevance for the field of administrative law results from the very common fact: a constitution is a basis and the framework of State administration and administrative law. "Administrative Law is the concretization of Constitutional Law", as F. Werner wrote 50 years ago and this sentence is something like the "European standards" on European soil. Therefore, the question arises, whether a constitutional norm is of a binding character, whether a norm contains a general objective for all State powers, or is it crucial also for the administration when elaborating programs, sub-laws and applying discretional powers. Constitutions consist of norms, the most popular are the norms, which fix the fundamental rights and freedoms. However, the complex systems of constitutional law (national) have a number of types of constitutional norms, which have different functions and-most of all different binding character. These types are usually the result of a review by a constitutional court. Such decisions raise doubt when constitutions order the "direct effect" of their norms. But the authors of constitutions sometimes have in mind "rights", which can exist only in a country of dreams. Or after decades, the facts changed but the constitutional norm still exists. If amendments to a constitution are impossible, the only way out is re-interpretation of such norms. Otherwise, the constitution carries a contradiction, which weakens the authority of a constitution.

This article shall present a comprehensive oversight of these categories in order to enrich the discussion on Constitutional law in Ukraine. The description of these types follows the categorization, proposed mainly by German authors, who included comparative law approaches on this topic. The picture of these categories shows an impressive number of such categories and offers arguments to deal with questions on the Constitutional law of Ukraine.

Key words: Constitution, norms of Constitutions, fundamental law, fundamental rights, institutional guarantees, programme provisions, constitutional objectives.

${ }^{1}$ This article was published first in "Ukrainian Law Review" (Український правовий часопис, 2003, № 2(7), с. 78-90). This version has been shortened and the refences have been edited. 


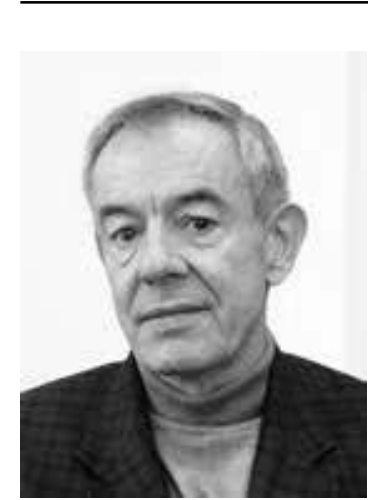

Dr. Bernhard Shloer, Long-term Lecturer German Academic Exchange Service, Lawyer (Germany), $P h D$ in Law orcid.org/0000-0001-6230-8471 schloerbernhard@gmail.com

\section{Introduction}

Present-day constitutions comprise a wide variety of norms, whereas previous constitutions provided for no more than certain rights of citizens as regards the State (so-called "rights that protect against the State interference") or they just fixed the form of government.

So, today we have to deal both with an entire system of rights intended to protect the individual, a system of the citizens' rights to participate in policy - and law-making processes, with norms relating to the foundations of the political (governmental) system, as well as with particular programme provisions, constitutional objectives, and goals outlined for the State and society.

The objective of this article is to provide an oversight of the types or categories of constitutional norms, based on the experience of European constitutional theory.

The development of constitutional norms of various categories and their hierarchy may be viewed as one of the aspects of a general theory of constitutional law.

In short, constitutional norms could be divided into the following categories.

First of all, these are norms relating to legal responsibility, procedures, time limits, and territorial structure.

In terms of substance, constitutional norms might be grouped according to the criteria that define the range of societal duties, legal foundations of individual and citizens' rights, the organization of state power and electoral system.

It is clear that a general distinction remains between substantive constitutional norms (that is those answering the question: "what to do?") and procedural ones (those answering the question: "how to do?").

Furthermore, constitutional norms could be grouped into the following categories: general, definitive, principle-like, constituent, safeguarding norms, as well as operative and conflict norms (L. Yuzkov, 1998).

Textually, constitutional norms could be distinguished as empowering, binding, or requiring, as well as optional norms and norms governing a particular function.

To a large extent, the categorization of the constitutional norms according to the abovementioned criteria reveals that the norms are directly or indirectly distinguished by a degree of their regulating effect. Therefore it is reasonable to specify the criteria by which the norms are referred to the substantive category or, in other words, to the group of binding norms. 
Substantive norms put various obligations on their addressees and, hence, in any event, could serve as a reference point for the Constitutional Court to take a decision. On the one hand, this means that the State has some discretion in choosing the manner in which to take or execute its decisions. On the other hand, this is important in terms of safeguarding the legal protection as provided for by Article 55 of the Ukrainian Constitution (all below mentioned articles are those of the Constitution of Ukraine - B. S.).

The below mentioned categories are defined on the basis of constitutional courts' practice and research. However, the constitution itself, as a normative act and owing to the openness and pithiness of its language and words, may not be used as a source for the categorization of its specific provisions.

This article contains references mainly only to two major German publications as the number of monographs, commentaries, articles, and decisions of constitutional courts exceeds the physical capacities of a single author. Precisely, it is the great work of Klaus Stern "Das Staatsrecht der Bundesrepublik Deutschland", volume I "Grundbegriffe und Grundlagen des Staatsrechts, Strukturprinzipien der Verfassung" (Stern, 1984), Allgemeine Lehren der Grundrechte volume III/1 (Stern, 1988) and volume III/2 (Stern, 1994), and the publication "Handbuch der Grundrechte in Deutschland und Europa, Band II, Grundrechte in Deutschland, Allgemeine Lehren" volume I (Handbuch der Grundrechte in Deutschland und Europa, 2006) and volume II (Handbuch der Grundrechte in Deutschland und Europa, 2009), edited by Detlev Merten and Hans-Jürgen Papier. This article shall provide an overview and raise interest in this topic as a field for research and discussion.

\section{Fundamental rights}

The term "fundamental rights" is referred to by those constitutional norms that define certain personal rights of an individual/citizen. That is to say, these rights are exercised individually (Stern, 1988).

These rights may be directed against the State - in the sense that they oblige the State to refrain from interfering therein; hence, such rights are called the rights to protection (against the State interference). On the other hand, fundamental rights may also imply participation in relations that are only maintained or initiated by the State, and in such event, we deal with the right to participation (in state legal relations).

Thus, fundamental rights protect the citizen and prescribe how state authorities should act or what they should refrain from.

Among the fundamental rights, we should distinguish the following two opposite categories: fundamental rights that protect against the State interference (see item 2.1 below) and those that imply some opportunities to influence the State affairs (see item 2.2 below).

In addition, some fundamental rights may have a legal effect going beyond the scope of direct relations between the State and the citizen (State-citizen relations); these are so-called objective fundamental rights (see item 2.3 below).

The main functions of fundamental rights are to ensure freedom of a particular individual and his/her protection against the State interference. What these functions have in common is that they are directed namely against the State. In some circumstances, though, the rights may influence relations between private persons; in such event, we deal with so-called "influence on third parties" (see item 2.4 below). 
The Ukrainian theory of constitutional law distinguishes between the following fundamental rights: civil, social, economic, political, and cultural rights - that is, they are grouped according to the spheres of life they regulate.

\subsection{Rights to protection}

Rights to protection define the boundaries within which the State may act and which are generally may not be trespassed by the State. Going beyond these boundaries, that is, interfering in the protected spheres is only allowed if there are relevant constitution-based grounds. To illustrate, Article 30 of the Constitution of Ukraine guarantees the inviolability of the dwelling place; any interference with the exercise of this right is not permitted except such as is on the basis of a substantiated court decision on the examination and search of the dwelling place or is in urgent cases as specified by the Constitution, under a procedure established by law (Stern, 1988).

\subsection{Citizens' rights to participate in state legal relations and to appeal to the} state for action

Rights to participation - as distinct from rights to protection - imply no regulation of the State interference but enable the citizen to demand certain actions from the State. To be more specific, these rights define the objects for the State care and require that the State create and/or maintain the relevant conditions. That is to say, rights to participation intend to ensure effective opportunities for the particular conduct and existence of the citizen, whereas rights to protection oblige the State to respect the sphere of private life (Stern, 1988; Stern, 1994; Starck, 2006).

"Participation" is a comprehensive term, which, in particular, means the citizens participation in the policy-making process; his/her participation in administrative procedures may have an important effect on the citizen; his/her participation in the ordinary life. Therefore, the right to participation could be divided into several groups.

2.2.1. Social fundamental rights are the most meaningful category of social rights to participation. They constitute the fundamental rights that guarantee the individual's access to vital essentials.

For instance, Article 141 (3) of the Bavarian Constitution reads: "taking of wild fruits (in a forest) $\langle\ldots\rangle$ is permitted for everyone". This fundamental right is directed against the State (though, it may also be exercised against a private owner of the forest) and is also judicially enforceable. However, in real life, some social rights tend to be invoked even where respective fundamental right does not exist from the legal standpoint.

Another matter to what extent the "genuine" social fundamental rights are capable of having their legal effect allowing financial capacities of the State. However, a need for financial support to a particular social fundamental right may not be used as an argument against the very existence of such a right.

A possibility of enforcing a particular fundamental right judicially is another prerequisite for the existence of the right. There is no logic in the establishment without stipulating its enforceability. One could view the requirement as an argument that social fundamental rights may not exist if the respective constitution neither provides for a possibility of enforcing them through an individual constitutional complaint nor confers a right of legal remedy against State actions upon the citizens (or lacking actions). 
The decisive criterion to qualify a particular right as a social right is the existence of a specific claim to a thing the right to which may be asserted. This means that the individual has an enforceable subjective right or claim to a particular object, and such fact does not need to be further determined, specified by law, etc. Let us, for instance, imagine a situation that there is a constitutional norm that provides: "Together with the diploma very graduating student shall receive a copy of the Constitution of Ukraine in force". This provision expressly refers to the object that falls under the scope of respective right and, correspondingly, implies a possibility of lodging a claim as regards the legally bound party (here - regarding the State as it presents state diplomas) and, if need be, enforcing this right in a court - in the event of the State failure to present the due copy of the Ukrainian Constitution.

A different matter is the formulation of a right such as the right of everyone for adequate housing for a human being. In this case, the right is not worded as unambiguously as in the case above. Indeed, the term "housing" should be understood differently and the phrase "decent for human being" is even more multivocal. In this context, we could note that some rights laid down in the Ukrainian Constitution providing for a certain action on the part of the State as, for instance, the right to labor (Art. 43), to rest (Art. 45), to social protection (Art. 46), to a sufficient standard of living (Art. 48), to health protection and medical care (Art. 46), to education (Art. 53), as well as the mentioned right to housing (Art. 47).

Therefore, a special attention should be paid to the question whether these norms imply a sufficiently specific right of an individual to certain actions by the State, that is whether they constitute social fundamental rights or they need to be additionally specified by legislative means. In fact, the extent to which such rights are specified in the provisions determines how well these rights could be defended (requested) in court. If a certain right is provided for in general terms, the respective norm needs to be specified by legislation. In these circumstances, we deal with a situation when the constitution does not contain a specific provision on a certain right, that is, it does not provide a particular social fundamental right. This type of norm should be qualified in a different way (see in this context, items 2.2.2 and 3.4).

2.2.2. There are some socially oriented constitutional norms, applied to the sphere in which the State is obliged to take certain actions (render services) in spite of the fact that an individual has not acquired the relevant constitutional right, that is, he/ she is not entitled to demand these particular actions. Though, the individual has the right to be treated equally with others to be given a benefit/service in pursuance of an administrative action.

However, the person's opportunity to exercise his/her rights depends on whether the particular social right to the State actions or services has been legislatively fixed. This is a deficiency in comparison with the opportunity to exercise specifically formulated fundamental right. Most clearly, consequences of this problem reveal themselves in judicial proceedings when it appears impossible to provide a remedy for a claim of a right to the State actions if this right is of abstract character.

Therefore, a particular social right to actions (services) on the part of the State can be effectively realized in the form of these very actions (services) assisting the citizens in their life and activities or in the form of social security if such actions (services) are 
regulated by ordinary law and if they are only appealable before court within the specified scope.

2.2.3. Political rights to participation are the rights to participate in elections and in any other public control and decision-making aimed to organize people's lives at the nationwide and regional levels. As these rights are of significance to democracy, they are commonly well regulated legislatively and based on proper safeguards for being defended in court.

\subsection{Institutional guarantees}

The fundamental rights comprise not only the abovementioned individual-legal element (item 2.2) but also an objective-legal one (Stern, 1988; Kloepfer, 2006). The latter means, in particular, the constitutional-legal protection of legal institutions and existing establishments that are provided or recognized by the constitution as well as those intended to promote the exercise of the fundamental rights.

Here, the term institution means a particular segment of law (for instance, legislation on inheritance) or a specific establishment and a particular set of legal norms logically related to such an establishment. To illustrate, freedom of scientific research may not be protected unless there exist relevant establishments as well as legislative regulation in the sphere of scientific self-government.

It is interesting to consider the institutional guarantee in terms of legal procedure. As evident from its concept, this guarantee does not apply to particular persons and, therefore, may not infringe any rights and freedoms. Therefore, the constitutional court is not empowered to examine whether it has complied unless the particular constitutional authority has lodged a complaint pursuant to the relevant procedure.

For instance, the Ukrainian Constitution provides local self-government (Article 7), specifies its organization, and powers (Article 140 et seq.). The consequence is that, although the Government and, especially, Parliament are empowered to regulate the type, manner, and volume of control over local self-government, they are not authorized to abolish local self-government or exercise a control that makes it needless or meaningless.

Another example is marriage. This is a form of coexistence, which is maintained only due to the respective legislative regulation. On the one hand, the protection of the marriage means that each spouse has the right to be protected individually and, on the other hand, that the marriage should be protected as a social institution. This also implies that a married individual is not entitled to constitutional protection of his/her rights arising out of the marriage, whereas the marriage, as an element of the legal order is subject to such constitutional legal protection. This protection is primarily directed against the legislative authority.

An interesting form of the institutional guarantee is contained in paragraph three of Article 49 of the Constitution of Ukraine, which provides that the existing network of health protection institutions should not be reduced. This prohibition may be understood as protection, under the constitutional legal guarantee, the existence of each particular health institution (for instance, a hospital).

If state authorities proceed from the assumption that it is the "network" that should be protected, they could be more flexible in their actions as the network as such is not a goal in itself, that is, it does not require the protection for the sake of its own existence. Then, 
it would be open to them to take relevant decisions concerning the network, depending on the medical functions, performed for the community. Any changes in this context (for instance, a substantial decrease in the number of residents of the particular area) may influence the decision on whether such very medical establishment is necessary or unnecessary for this locality. This approach excludes the possibility of lodging a complaint alleging the unconstitutionality of a decision to close a particular hospital.

We could make a distinction between the institutional guarantee and the fundamental rights in that the fundamental rights are intended to protect the individual freedom and equality, whereas the institutional guarantee involves the constitutional protection of certain institutions.

There is a general trend towards expanding the scope of such protection - making, at the same time, the constitutional legal safeguards more specific and, thus, strengthening the role of constitutional courts in this process.

In Germany, for example, the constitutional legal protection was at first granted to such institutions as ownership, marriage, and local self-government, whereas now it extends to self-government of higher academic establishments, professional civil service, and independent judiciary. Moreover, under debate is the question whether it is also expedient to extend the institutional guarantee to the press, television, radio broadcasting, and trade unions, as well as to remuneration based on a wage rate.

\subsection{The fundamental rights' influence on private law relations}

The issue of the fundamental rights' influence on relations of private persons is directly connected with the issue whether the fundamental rights are capable - and if so, in what manner - of influencing the relations between private persons. With this influence, the application of the fundamental rights goes beyond the scope of the "State-citizen" relations (Stern, 1988; Papier, 2006).

To resolve the mentioned issue, we have to identify the addressees of the fundamental rights, that is, we should see who is actually bound by the fundamental rights or whose discretion appears to be restricted by their effect. It should be accepted that such restrictions primarily concern the State (all its branches of power: legislative, executive, judicial authorities) - this is essentially explained by the very character and emergence of the fundamental rights as rights to protection.

The question of whether any influence on third parties may only be relevant with respect to the fundamental rights whose protected scope involves regulations capable of being violated by natural persons. For instance, it is only the State that may become an infringer of the right to a remedy in connection with a deprivation of citizenship, which means, therefore, that provisions of Article 25 of the Ukrainian Constitution may never be directed against a natural person as an addressee of the fundamental rights.

However, there are spheres in which it is possible that a natural person may become the subject of violated fundamental rights as well. Private "power" might be comparable with the State power in these spheres.

A typical example is the right to strike as a protest against the private employer or the provision of equality between women and men in employment. We could also add the following to this: freedom of association, as provided for by employment legislation, against the private employer; all aspects of equality on employment and education in leg- 
islation; the protection of human dignity as laid down in employment and matrimonial legislation, freedom in choosing his/her profession, freedom of religion, as well as the so-called internal freedom of the press (freedom of thought within the editorial board).

The influence of a particular fundamental right on a private sphere may be conditioned by various grounds. In particular:

- it is possible that a particular fundamental right serves as the basis for the influence on third parties. For instance, Article 51 of the Ukrainian Constitution provides an obligation of children to care for their parents. Relations between parents and their children are regulated by civil law, such relations are under the legal influence of Article 51 of the Ukrainian Constitution;

- the influence on third parties may be fixed, as a postulate for all fundamental rights, in the constitution. For instance, the Swiss Constitution provides the following: "legislative and judicial authorities shall ensure that the fundamental rights also respected in relations among private parties. $<\ldots>$ Those who exercise their fundamental rights shall respect the fundamental rights of others. First and foremost, nobody shall be entitled to violate the fundamental rights by abusing their own powers".

In the Ukrainian Constitution, the influence on third parties is generally conditioned by provisions of Article 68, which implies that nobody is allowed to violate the rights and freedoms, honour and dignity of other persons. Therefore, this prohibition is in force within the sphere of civil legal relations. However, it should be noted that it only concerns relations between natural persons; as to legal entities, the influence on third parties is not provided. The question of whether Article 68 covers the rights and freedoms regulated by law need to be scrutinized separately.

The State may also come under the obligation to protect certain fundamental rights within the sphere of civil legal relations between natural persons (for instance, Article 2 of the International Convention on the Elimination of All Forms of Racial Discrimination) by virtue of international treaties to which this State belongs.

If the mentioned above grounds are absent, the influence on third parties may be achieved by other means, in particular:

- the fundamental rights are provided for as rights having a direct effect on third parties as these rights are subjective public rights that protect natural persons and provide safeguards against their violations. Or, the fundamental rights might be viewed as fundamental principles of social life, which are also of significance to legal relations between citizens;

- the fundamental rights are given an opportunity to indirectly influence third parties. The State is obliged to respect and protect the fundamental rights. This is primarily achieved through legislative and judicial measures.

The court should correct the conduct of private persons if it runs counter to the compliance with the fundamental rights. Judicial authorities are not empowered to alter legislation in force. They are obliged to supervise whether citizens exercising their fundamental rights come across a general warning (such as "unlawful damage") or unspecified notions (such as "rules of good behaviour") that entail a value judgment.

A classic means to strengthen the compliance with the fundamental rights within the scope of State-citizen relations and relations between the citizens is the introduction of the institution of "public order" into criminal legislation (for instance, into Articles 1 and 239 of the Ukrainian Criminal Code). This notion may not be applied unless there is the 
respective specifying interpretation. It implies the types of behaviour legislatively authorized as well as "social norms", that is, the norms based on a general understanding and feeling for the law: on customs, traditions, moral rules, etc. A similar approach is reflected by Article 5 of the effective Civil Code of the Ukrainian SSR and is consistent with the respective Central European tradition. A new norm capable of having the alike effect is laid down in Article 13 of the new Civil Code.

\section{Other categories of substantive constitutional norms}

Apart from the fundamental rights, a notional influence on the rights and duties is also caused by other constitutional norms, among which are programme provisions, constitutional objectives, outlined social and national goals, and provisions on the constitutional order.

\subsection{Programme provisions}

Programme provisions are those provisions of the constitution, which have no binding force. Hence, their violation may not become a matter to complain in court. These provisions only reflect what the constitution-maker intended to achieve in the future in terms of organization of particular spheres of national and social life (Stern, 1988).

For instance, the constitutional norms whose binding force is not provided to be unexercisable have been treated by the Bavarian Constitutional Court as programme provisions. As programme provisions, we could also consider provisions of Articles 11, paragraph four of Article 49, and paragraph three of Article 51 of the Ukrainian Constitution. These provisions may be considered not binding and they only quite expressly outline the directions for the development.

There has been much discussion about programme provisions of modern constitutions to the effect that the constitution should not contain provisions that have no binding force. That is why such norms (programme provisions) are for the most part deemed to be "constitutional objectives" rather binding that not. The Ukrainian Constitution also guarantees the "direct effect" of its norms (paragraph 3 of Article 8). Thus, reasoning from this Article, programme provisions may only be binding. The absence of any qualifications concerning the term "norms of the Constitution of Ukraine" in the phrase "The norms of the Constitution of Ukraine are norms of direct effect" excludes any possibility of differentiating between norms contained in the provisions preceding Article 8 and those contained further on the text, it does not allow to deprive any norm or any part of its binding force.

\subsection{Constitutional and legislative objectives}

Constitutional objectives, which are sometimes referred to as legislative ones, are specific tasks to be solved by parliament and other bodies of state power within a legislative or any other process. For instance, Article 45 provides the right to rest, while paragraphs two and three of this Article specify the range of issues to be settled by enacting the respective laws; these provisions outline the substance of the future norms.

Since the State has a wide discretion in taking political decisions and it is impossible to judicially control the use of such powers, the defense of constitutional objectives in court is only realizable in extraordinary cases.

It is explained by the fact that a constitutional objective in itself may not infringe any rights or freedoms. Judicial proceedings against a particular constitutional objective are only possible if this objective specifies certain actions or a precise timeframe for its fulfillment and also if an omission (inaction) of a competent state authority gives rise to 
a serious risk or any other threat to the national constitutional order, or if the state authorities arbitrarily take unjustified decisions.

A common feature of such cases is that a failure to pursue or untimely pursuance of constitutional objectives appear to be detrimental to the citizen's opportunity to exercise certain rights or perform particular duties.

It is necessary to dwell upon the issue why the term constitutional objective is often used concurrently with the term legislative objective - and, in this context, to identify the scope of these notions to be discussed below.

The term constitutional objective means an objective as defined by the constitution-maker in the text of the constitution. The constitutional objective does not specify who is logically and necessarily the addressee - this could be the legislative body, an executive authority or the whole political machinery. We could also suggest that a particular constitutional objective concerns each individual citizen as well.

Furthermore, constitutional objective does not necessarily involve a particular type of actions, so this notion should be construed widely.

Another matter is the constitutional objective, which concerns parliament, as it means that only this body is empowered to adopt legislation. Such an objective specifies a particular form of the State action, which is namely its legislative activity. So, the notion of the legislative objective is narrower.

As a legislative objective, we could consider provisions of paragraph one of Article 24, which stipulates that conditions ensuring equality of citizens before the law should exist, whereas we could view paragraph one of Article 47 as a constitutional objective since this provision provides the State obligation to ensure that citizens are provided with housing. The "State" in this context means all branches of state power, while the judiciary may become involved, at best, in choosing for the constitutional objective a reasonable interpretation to be an adequate reflection of its substance as possible.

Different branches of state power pursue one and the same constitutional objective by different means are the following: parliament - by enacting legislation specifically regulating the issues of lease and construction of housing; the central and local authorities - with the help of subsidies and of their own construction efforts.

\subsection{Provisions on the constitutional order}

Provisions on the constitutional order define the main characteristics of the particular State, such as republic, democratic, law-based, or social State. These are invariable pillars of that constitutional order, fixed in the constitution. For this reason, they are also called constitution-based fundamental principles of constitutional order (Stern, 1984).

These are the State characteristics based on consensus as regards their role and substance; nevertheless, these provisions are flexible in essence. Their influence is so manifold that it defies description - indeed, this influence continuously changes with the lapse of time. The typical example is the notion of social State. Most of the provisions on the constitutional order may be also qualified as outlined national goals.

\subsection{Outlined national goals}

Outlined national goals are constitutional norms obliging all state authorities to consider the substance and the main ideas of constitutional state goals in their activities (Papier, 2006; Lange, 2009). 
These norms generally apply to the legislative body, though they are also capable of having a guiding influence on the activities of the executive body.

Thus, from a legal standpoint, they are binding, but a citizen may not rely on them as the basis for bringing an action before a court, because, primarily, the mentioned norms' influence on state authorities' activities (the requirement to respect the national goals) may not essentially entail violations of human and citizens' rights and freedoms. Indeed, a complaint against such a violation should be first of all based on the existing fundamental rights.

The binding character of a particular provision defining a national goal depends on how this goal is formulated in the constitution. The text of the constitution should contain formulations whose interpretation could prompt the state authorities to take actions or could provide other organizational opportunities and such formulation should not merely reflect general aspirations of society.

As an example of the latter approach, we may consider the constitutional provision to the effect that the development of sports is one of the important spheres of social life. On the other hand, constitutional norms requiring the creation of national educational establishments are of binding character.

These and other numerous examples show that it is not easy to make such a distinction as it is necessary for so doing to consider particularities of this category of norms (outlined national goals).

In fact, the quality of a particular norm depends on the extent to which its effect is binding. In this context, any duties and obligations prescribed by law should be clearly defined or, at least, there should exist prerequisites for defining them. This, in particular, stems from the principle of law-based State (based on the rule of law).

The national goal status may only be attached to those constitutional provisions that define specific aspects of statehood. Then, we could deem the principle of democracy, the principle of social State, and the parliamentary system of governance to be national goals.

An additional effect, similar to that of national goals, may also stem from the fundamental rights and other constitutional norms, precisely, the right to be protected against the State interference; nevertheless, this is at the same time deemed to be a national goal, too, which obliges all state authorities to respect and protect human dignity.

Such notional influence has much in common with the law-based essence of the fundamental rights and, therefore, it should be distinguishable. So, the essence of the fundamental rights as defined by law may vary depending on the influence born in mind. These norms may be considered both as constitutional organizational guarantees and as national goals.

Provisions on national goals appear to be problematic if they come into conflict with each other and/or with the fundamental rights.

Some commentators believe that the relationship between the principle of law-based State and the principle of social State is an example of such a conflict.

According to the law-based State principle, the greatest achievement is lawfulness. This means that the State may not resort to any interference unless the measure is prescribed by law. 
In contrast, the social State principle refers to the necessity for the State to provide certain benefits. These benefits, however, may only be specified by executive power itself, which then should be viewed as a legislative function assigned to this power, in violation of the principle of separation of powers.

Moreover, the law-based State principles require that any actions by the State should be defined in a way, and based on preconditions, which would enable their interpretation with the help of some generally recognized methods.

At the same time, the notion of "social" is rather vague and it is actually impossible to provide it a precise and exhaustive definition - though, this does not influence the processes of recognizing and exercising the principle of social State.

\subsection{Norms that regulate the state tasks}

The State tasks are those which the State is entrusted with under the constitution. They are performed within a scope determined by the relevant subject-matter, which makes them distinguishable from national goals. For instance, a national goal is the maintenance of internal security, whereas the corresponding state task ensures the operational readiness of the police (Stern, 1984).

Let us try to find a logical conclusion as to what provisions of the constitution may be viewed as tasks of the State.

In its actions, the State is guided by the constitution. So, a particular task of the State is reflected in the constitution, that is, the respective powers should be constitutionally fixed.

Without such powers, the State is not entitled to undertake the particular task. Therefore, such constitutional powers may be deemed to be a particular manner of defining state tasks, which is also called "implicit state tasks, since they are fixed not as independent tasks but only implied by the context of the tasks intended for the organization of a particular sphere of life with the help of law".

A problematic form of the State task is the one fixed by a constitutional norm.

As to the necessity of introducing provisions on the State tasks into the constitution, there exist the following doubts.

It is believed that constitutionally fixed tasks restrict the parliament's and government's freedom of political actions and the form in which they are fixed (through a constitutional norm) "cement" their consequences for a long time. This entails the risk of restricting the freedom of policy (political governance) and the impossibility of adapting the policy to new circumstances.

Furthermore, if the tasks are constitutionally fixed, it is difficult and sometimes impossible, to calculate financial capacities of the State for the future. In particular, a situation may arise where the fulfillment of a particular task of the State could depend on the State's entire budget.

Finally, each constitutional task of the State should be viewed in the light of a possible control thereof on the part of judicial power.

It has been noted above that constitutionally fixed tasks of the State threaten to violate one of the basic freedoms, which is free of political governance, that is, this task affects an important aspect of the functioning of one of the branches of powers. On the other hand, if this sphere is subordinated to another branch of power - judiciary, this may actually shift the balance of powers from one branch to the other. 
The constitution directs the fulfillment of a particular task or restricts the discretion in choosing the means to perform it.

On the one hand, the State tasks are restricted by the fundamental rights and, on the other hand, by excluding the possibility of creating a totalitarian State. The constitutional State does not assume the whole potential of possible powers as it should leave to each citizen and any group, association, etc., the spheres for socially beneficial activity, which spheres may not be reflected in the constitution.

There is also a principle of subsidiarity, which confers upon non-governmental organizations priority rights regarding some tasks and, correspondingly, prohibits the State from undertaking them for itself.

The constitutional-law character of state tasks means that they should be differentiated according to the extent of State involvement in their performance:

- tasks carried out entirely by the State - for instance, those relating to the State's defense;

- tasks in whose performance the State cooperates with independent organizations;

- certain tasks performed by private (nongovernmental) organizations under control on the part of the State, which influences this process by means of economic levers, planning, and subventions;

- tasks whose performance is encouraged to be of non-governmental (private) character within a particular sphere and promoted by the State.

\section{Constitutional norms of organizational and procedural law character}

Apart from the mentioned above, lots of other classifications of constitutional norms exist. The discussion of the issue relating to the classification of constitutional norms according to the fact whether they define or do not define the rights and duties since it is this characteristic that determines possibility/impossibility of judicial control over their observance is below.

The norms that constitute just a statement (for example, "The capital of Ukraine is the City of Kyiv") are certainly important but they could only become a matter for a legal dispute in an extraordinary situation such as in the event of a putsch or revolution, that is, where the constitution itself was called into doubt.

\subsection{Norms of competence}

These constitutional norms regulate issues of competence of individual bodies of state power and their subdivisions. They also regulate certain powers of such bodies. For instance, the legitimate competence of such a constitutional body as parliament is its power to adopt laws (Stern, 1984).

Norms of competence, owing to the related powers, are norms of substantive character.

The control over the compliance with norms of competence may be exercised by the constitutional court. Here, two ways are possible: firstly, a special complaint against a violation may be lodged by one state authority against another (complaints of constitutional bodies). Secondly, a complaint against actions/measures taken by bodies that do not have the relevant competence or have not been delegated the respective powers may be lodged under the administrative procedure, because a violation of norms of competence could be one of the reasons for unlawfulness of particular administrative actions/measures. 


\subsection{Procedural norms}

These constitutional norms regulate procedural aspects of state authorities' activities, such as the procedure for adopting legislative acts or for appointing judges (Stern, 1984).

Violations of procedural norms may be complained in court. This may be done separately from the decision taken under the procedure in issue or may also involve challenging such a decision.

German jurisprudence in the resolution of constitutional disputes could be of some interest in this context, which qualifies a procedurally wrongful adoption of a particular law by the parliament as a ground for declaring such law unconstitutional - on account of the fact that it has been adopted without complying with the constitutional procedure.

\subsection{Norms on review (of constitutional norms)}

These norms regulate the entire set of measures on review and amendment of the constitution. Although they are close to procedural norms, their characteristics require their qualification as norms of competence. This primarily means that decisions taken on the basis of these norms are subject to review by the constitutional court (Stern, 1984).

\subsection{Law-making norms}

This category of norms includes, first of all, the norms of competence which entrust the relevant state authorities with law-making powers to adopt laws, issue decrees, resolutions, directives, etc. However, a situation may arise where a right originates in a different way.

4.4.1. Autonomous law-making norms. A special aspect of these norms' operation is the fact that a right may originate from a particular constitutional norm independently and directly, without any need of special actions by legislative or any other competent authority - the respective right or respective duty arise concurrently with a particular prerequisite provided by the constitution.

As an example, we could note a provision of the German Constitution on equality of children whether borne in or out of wedlock. Legislatively, such equality was supposed to come into effect after a specified period. Before it expired, the Federal Constitutional Court had adopted a decision that the expiry of the period shall mean the entry into force of the right arising from courts' judgments concerning this matter which judgments would be held in the future (the so-called judicial law).

4.4.2. Empowering law-making norms. This category also includes norms of competence which empower the relevant state authorities to adopt laws, resolutions, to issue decrees, directives, etc. However, the constitutionally fixed competence in itself is not sufficient to create law. For this purpose, a law-making procedure should be followed, which is the duty of a relevant competent authority.

\subsection{Law-annulling norms}

The classification of law-annulling norms is similar to the corresponding classification of lawmaking norms. These are divided into autonomous law-annulling norms and law-annulling norms that require additional norms. As an example of such norms, we could consider in particular, paragraph two of Article 152, according to which, laws and other legal acts should be deemed to be unconstitutional if the Constitutional Court of Ukraine adopts the decision on their unconstitutionality. 


\subsection{Transitional provisions}

Any changes in the political or legal system call for the solution of transitional problems for legal and practical reasons. Such norms of transitional character are additionally included in the new constitution or new law.

As a rule, transitional provisions are limited in time as otherwise, they would lead to a situation where two legal system duplicate each other, that is, lead to legal instability.

However, the time frame could be formulated in the following way: a particular transitional provision is supposed to terminate immediately after a specified event in the future, such as, for instance, the adoption of a particular law.

\subsection{Preamble}

As to this category of norms, the only relevant question is whether the preamble has a binding legal character and, if so, to what extent it is binding.

Technically, the preamble is put before the main body of the constitution structured in articles so that it could be visually identifiable. Also, the preamble is usually formulated in a stylistically different manner: its provisions look like fundamental political declarations rather than legal formulations. That is why a possibility of applying legal criteria to the preamble is called into question.

According to the German theory of state and law, the preamble should, "by a set of concise phrases, depict historical preconditions for the adoption of the constitution, the reasons that induced the lawmaker to adopt it, as well as the relevant intentions - expressing in this way the significance and the goal of the constitution".

This means that the preamble is not only a "historical record" without any legal meaning. Indeed, the significance of the preamble in the constitutional-political sphere is still a controversial issue; while such notions as "human rights and freedoms" and "democratic, social and law-based state" are such legal categories that define principles of statehood.

An eloquent evidence of the legal significance of the Preamble, as part of the Ukrainian Constitution, is its last sentence, which reads that the Verkhovna Rada adopts this Constitution: it is quite certain that this formulation has a clearly expressed legal meaning, which determines characteristics of the national goal.

So, the preamble may be deemed to belong to the system of constitutional norms.

\subsection{Final provisions}

These norms primarily concern the time for the constitution's entry into force. Their binding legal force is confined by the legal fixing of the validity, without creating any other legal consequences. Such norms are often included in transitional provisions, but their legal significance should be discussed separately (see item 4.6 above).

\section{Intersection and multiple meaning of constitutional norms}

Constitutional norms may be systematized at the same time according to more than a few categories mentioned above. For instance, a particular provision on the constitutional order may concurrently be an outlined national goal.

Similar transformations take place due to changes in the interpretation of the respective norm, which gets therewith a narrower or wider meaning.

\section{Conclusions}

The differentiation of constitutional norms according to their law-underlying substance and the related possibility of judicial control over their compliance reveals a tight 
entwinement of rights, freedoms, and legal conditions, which, by virtue of Article 150 of the Constitution of Ukraine, may become a matter of legal disputes between the highest state authorities.

Nonetheless, we believe that this entwinement has some "gaps" - we may find them where a scrutiny of the notion of "right does not disclose the existence of a claim as such and, hence, of the relevant prerequisites for the judicial enforcement, which actually means that the particular human right is not involved.

However, such intersections in the qualification of norms are also possible where certain social preconditions, existed at the time of introducing the relevant norm have undergone substantial changes with time.

\section{Bibliography:}

1. Юзьков Л. Конституція незалежної України: в 3 кн. / за заг. ред. С. Головатого. К., 1998. Кн. 3. Ч. 1: Документи. Стенограми. 340 с.

2. Stern K. Das Staatsrecht der Bundesrepublik Deutschland, Band I, Grundbegriffe und Grundlagen des Staatsrechts, Strukturprinzipien der Verfassung. 2. ed. Munich: Publisher C.H. Beck, 1984. 1111 S.

3. Stern K. Das Staatsrecht der Bundesrepublik Deutschland, Allgemeine Lehren der Grundrechte, Band III/1. Munich: Publisher C.H. Beck, 1988. 1643 S.

4. Stern K. Das Staatsrecht der Bundesrepublik Deutschland, Allgemeine Lehren der Grundrechte Band III/2. Munich: Publisher C.H. Beck, 1994. 1918 S.

5. Handbuch der Grundrechte in Deutschland und Europa, Band II, Grundrechte in Deutschland, Allgemeine Lehren I / ed. D. Merten, H.J. Papier. Heidelberg: Publisher C.F. Müller, 2006. $1000 \mathrm{~S}$.

6. Handbuch der Grundrechte in Deutschland und Europa, Band III, Grundrechte in Deutschland, Allgemeine Lehren II / ed. D. Merten, H.J. Papier. Heidelberg: Publisher C.F. Müller, 2009. 1200 S.

7. Starck Chr. Teilhaberechte. Handbuch der Grundrechte in Deutschland und Europa, Band II, Grundrechte in Deutschland, Allgemeine Lehren I / ed. D. Merten, H.J. Papier. Heidelberg: Publisher C.F. Müller, 2006. S. 709.

8. Kloepfer M. Einrichtungsgarantien. Handbuch der Grundrechte in Deutschland und Europa, Band II, Grundrechte in Deutschland, Allgemeine Lehren I / ed. D. Merten, H.J. Papier. Heidelberg: Publisher C.F. Müller, 2006. S. 921.

9. Papier H.J. Drittwirkung der Grundrechte. Handbuch der Grundrechte in Deutschland und Europa, Band II, Grundrechte in Deutschland, Allgemeine Lehren I / ed. D. Merten, H.J. Papier. Heidelberg: Publisher C.F. Müller, 2006. S. 1331.

10. Lange K. Grundrechtliche Besonderheiten in den Landesverfassungen. Handbuch der Grundrechte in Deutschland und Europa, Band III, Grundrechte in Deutschland, Allgemeine Lehren II / ed. D. Merten, H.J. Papier. Heidelberg: Publisher C.F. Müller, 2009. S. 1170.

\section{References:}

1. Yuzkov, L. (1998). Konstytutsiia nezalezhnoi Ukrainy: v 3 kn. [The Constitution of Independent Ukraine: in 3 vol.]. Kyiv, Kn. 3. Ch. 1: Dokumenty. Stenohramy [Vol. 3. Part 1: Documents. Records]. [in Ukrainian].

2. Stern, K. (1984). Das Staatsrecht der Bundesrepublik Deutschland, Band I, Grundbegriffe und Grundlagen des Staatsrechts, Strukturprinzipien der Verfassung. 2. ed. Munich: Publisher C.H. Beck. [in German]. 
3. Stern, K. (1988). Das Staatsrecht der Bundesrepublik Deutschland, Allgemeine Lehren der Grundrechte, Band III/1. Munich: Publisher C.H. Beck. [in German].

4. Stern, K. (1994). Das Staatsrecht der Bundesrepublik Deutschland, Allgemeine Lehren der Grundrechte Band III/2. Munich: Publisher C.H. Beck. [in German].

5. Merten D., Papier H.J. (ed.) (2006). Handbuch der Grundrechte in Deutschland und Europa, Band II, Grundrechte in Deutschland, Allgemeine Lehren I. Heidelberg: Publisher C.F. Müller. [in German].

6. Merten D., Papier H.J. (ed.) (2009). Handbuch der Grundrechte in Deutschland und Europa, Band III, Grundrechte in Deutschland, Allgemeine Lehren II. Heidelberg: Publisher C.F. Müller. [in German].

7. Starck, Chr. (2006). Teilhaberechte. Handbuch der Grundrechte in Deutschland und Europa, Band II, Grundrechte in Deutschland, Allgemeine Lehren I / ed. D. Merten, H.J. Papier. Heidelberg: Publisher C.F. Müller, S. 709.

8. Kloepfer, M. (2006). Einrichtungsgarantien. Handbuch der Grundrechte in Deutschland und Europa, Band II, Grundrechte in Deutschland, Allgemeine Lehren I / ed. D. Merten, H.J. Papier. Heidelberg: Publisher C.F. Müller, S. 921.

9. Papier, H.J. (2006). Drittwirkung der Grundrechte. Handbuch der Grundrechte in Deutschland und Europa, Band II, Grundrechte in Deutschland, Allgemeine Lehren I / ed. D. Merten, H.J. Papier. Heidelberg: Publisher C.F. Müller, S. 1331.

10. Lange, K. (2009). Grundrechtliche Besonderheiten in den Landesverfassungen. Handbuch der Grundrechte in Deutschland und Europa, Band III, Grundrechte in Deutschland, Allgemeine Lehren II / ed. D. Merten, H.J. Papier. Heidelberg: Publisher C.F. Müller, S. 1170.

\title{
КАТЕГОРІЇ КОНСТИТУЦЙНИХ НОРМ
}

\author{
Бернхард Шлоер, \\ викладач Німецької служби академічних обмінів, \\ юрист (Німеччина), доктор юридичних наук \\ orcid.org/0000-0001-6230-8471 \\ schloerbernhard@gmail.com
}

У статті розглянуто сферу конституиійного права, фундаментальну теорію писаних конституцій. Актуальність для сфери адміністративного права постає 3 поширеного факту: конституція є основою та межами державного управління й адміністративного права. Як писав Ф. Вернер 50 років тому, «адміністративне право - ие конкретизація конституціийного права», $і$ ие твердження $\epsilon$ чимось на кшталт «європейських стандартів» на європейській території. Таким чином, виникає питання про те, чи є конституційна норма обов'язковою, чи містить норма загальну мету для всієї державної влади або ж вона має вирішальне значення також для адміністрування під час розроблення програм, підзаконних актів та застосування дискреційних повноважень.

Конституиії складаються з норм, найбільш популярними є норми, які закріплюють основні права ц̌ свободи. Проте складні системи конституційного права (національного) мають низку типів конституційних норм, які мають різні функції та найчастіше різний обов'язковий характер. Зазвичай циі типи є результатом розгляду конституційного суду. Такі рішення викликають сумнів у разі, коли конституції назначають «прямий вплив» їх норм. Проте іноді автори конституцій мають на увазі «права», які можуть існувати лише в країні мрій. Або після десятиліть факти 
змінилися, проте конституційна норма все щзе існує. Якщз поправки до конституції $\epsilon$ неможливими, єдиним виходом є повторне тлумачення таких норм. Інакше конституція викликає протиріччя, щзо послаблює ї̈ авторитет.

Стаття має представити всеосяжний огляд наведених категорій із метою активізації обговорення конституиійного права в Україні. Опис ичих типів супроводжується категоризацією, запропонованою переважно німецькими авторами, які враховували підходи порівняльного права щуодо цієї теми. Опис иих категорій відображає їх значну кількість та надає аргументи для розгляду питань конституиійного права Украӥни.

Ключові слова: конституція, норми конституцій, основний закон, основні права, інституційні гарантії, програмні положення, конституційні цілі. 